\title{
Investigating aquifer contamination and groundwater quality in eastern Terai region of Nepal
}

\author{
Sanjay Mahato ${ }^{1,2^{*}} \mathbb{D}$, Asmita Mahato ${ }^{1}$, Pankaj Kumar Karna ${ }^{2}$ and Nisha Balmiki ${ }^{1}$
}

\begin{abstract}
Objective: This study aims at assessing the groundwater quality of the three districts of Eastern Terai region of Nepal viz. Morang, Jhapa, Sunsari using physicochemical characteristics and statistical approach so that possible contamination of water reservoir can be understood. pH, temperature, conductivity, turbidity, color, total dissolved solids, fluorides, ammonia, nitrates, chloride, total hardness, calcium hardness, calcium, magnesium, total alkalinity, iron, manganese, arsenic have to be analyzed to know the present status of groundwater quality.

Results: Results revealed that the value of analyzed parameters were within the acceptable limits for drinking water recommended by World Health Organization except for pH, turbidity, ammonia and iron. As per Nepal Drinking Water Quality Standards, fluoride and manganese too were not complying with the permissible limit. Electrical conductivity, total dissolved solids, chloride, total hardness, calcium hardness, manganese, and total alkalinity show good positive correlation with major water quality parameters. Calcium, magnesium, total hardness, calcium hardness and total alkalinity greatly influences total dissolved solids and electrical conductivity. ANOVA, Tukey, and clustering highlight the significance of three districts. Groundwater can be considered safe, but there is always a chance of contamination through chemical wastes in the heavily industrialized area of Morang and Sunsari Industrial corridor.
\end{abstract}

Keywords: Physicochemical, Terai, Nepal, Groundwater

\section{Introduction}

Groundwater can be defined as water contained in an aquifer matrix located beneath the surface in the saturated zone naturally containing dissolved mineral ions [1-3]. Factors like climate, slope, drainage conditions, water-rock interaction and anthropogenic activities contribute to the groundwater quality [4].

Electrical conductivity is the indicator of dissolved inorganic ions in groundwater. Total dissolved solids describe the inorganic salts and small amounts of organic matter present in water [5]. Low $\mathrm{pH}$ of water can cause gastrointestinal disorders [6]. Turbidity in water arises from the presence of very finely divided solids [6]. Dissolved minerals, especially divalent cations cause total

\footnotetext{
*Correspondence: Mahato.sanjay@gmail.com

${ }^{1}$ Aasra Research and Education Academy Counsel, Janapriya Tole, Biratnagar-7, Nepal

Full list of author information is available at the end of the article
}

hardness in water. Hardness caused by calcium is called calcium hardness, regardless of the salts associated with it [7]. Total alkalinity is the result of the presence of bicarbonates, carbonates and hydroxides of calcium, magnesium and sodium [8].

Excess of fluoride is associated with fluorosis, hyperparathyroidism, increased bone resorption, and skeletal deformity [9-11]. Excess chloride in water is usually taken as an index of pollution and reflected as tracer for groundwater contamination [12, 13]. Nitrate can reach groundwater as a consequence of agricultural activity, wastewater treatment and oxidation of nitrogenous waste products in excreta [14, 15]. Higher contents (up to $3 \mathrm{mg} / \mathrm{L}$ ) of ammonia are found in strata rich in humic substances or iron or in forests [16].

The high level of manganese causes nervous system disorder, sperm damage, impairments in fertility, nephritis, and nephrolithiasis [17-19]. Arsenic causes cancer [20], hypertension, and cutaneous abnormalities [21].

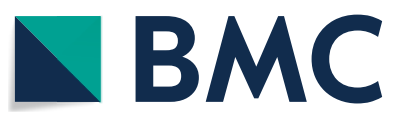

C The Author(s) 2018. This article is distributed under the terms of the Creative Commons Attribution 4.0 International License (http://creativecommons.org/licenses/by/4.0/), which permits unrestricted use, distribution, and reproduction in any medium, provided you give appropriate credit to the original author(s) and the source, provide a link to the Creative Commons license, and indicate if changes were made. The Creative Commons Public Domain Dedication waiver (http://creativecommons.org/ publicdomain/zero/1.0/) applies to the data made available in this article, unless otherwise stated. 
The objective of this study is to investigate the drinking water quality of groundwater via evaluation of eighteen parameters, determining concentration of contamination if present, comparing values with set standards of World Health Organization (WHO) and Nepal Drinking Water Quality Standards (NDWQS); and finding the correlation among the evaluated parameters.

\section{Main text \\ Methods \\ Study area}

The study area is located in the plain area of Eastern Development Region of Nepal comprising of three districts viz. Jhapa (area $1606 \mathrm{~km}^{2}$ ), Morang (area $1855 \mathrm{~km}^{2}$ ) and sunsari (area $1257 \mathrm{~km}^{2}$ ) (Fig. 1). These districts have a tropical climate with annual mean temperature range from 18.8 to $30.1{ }^{\circ} \mathrm{C}$. The annual normal rainfall is 2000-2500 mm [22]. Parts of Sunsari and Morang are a heavily industrialized area due to industrial corridor.

\section{Analytical methods}

A total of 175 groundwater samples which included 135 borewell and 40 tubewell samples were collected from January, 2015 to September, 2016. Sampling was carried out using pre-cleaned polypropylene bottles. Groundwater was collected in containers after flushing out the tubewells or borewells (minimum $10 \mathrm{~min}$ ) in order to get the fresh groundwater. Collected samples were preserved at $4{ }^{\circ} \mathrm{C}$ and taken into the laboratory for analysis. The parameters were selected on the basis of their relative importance in pollution potential on groundwater. All the physicochemical parameters were determined by the standard methods recommended in American Public Health Association [23].

Physical parameters like temperature, $\mathrm{pH}$, electrical conductivity (EC) and total dissolved solids (TDS) were measured using Thermo Scientific Orion 5-Star Plus instrument. Turbidity (TUR) of the samples were determined by using portable turbidity meter (Hanna instruments HI 93703 Microprocessor).

For chemical parameters such as total alkalinity (TA), total hardness $(\mathrm{TH})$, calcium hardness $(\mathrm{CH})$, major

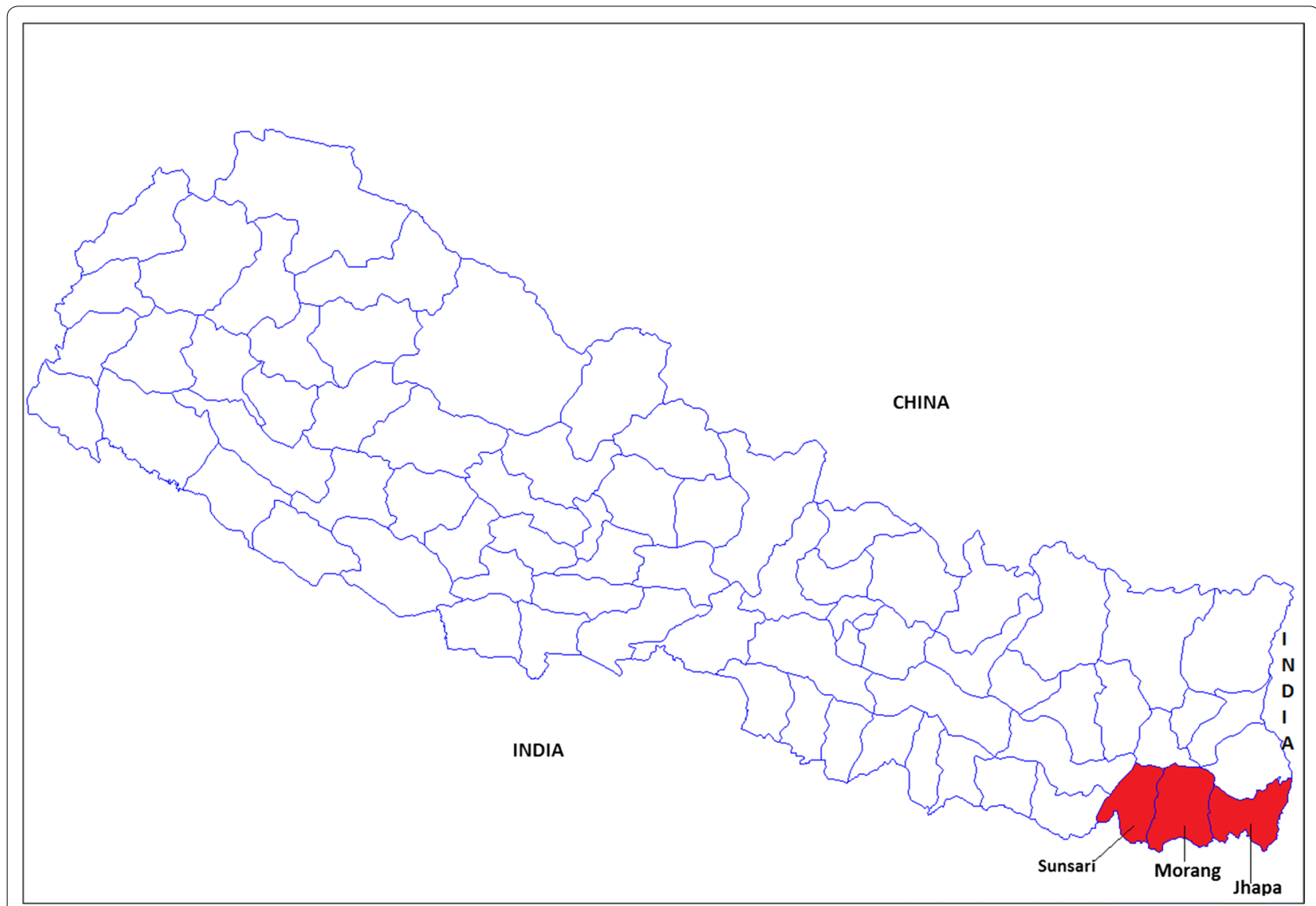

Fig. 1 Study area in Eastern Terai of Nepal namely Sunsari, Morang, Jhapa. (Map cited from https://en.wikipedia.org/wiki/List_of_districts_of_Nepal) 
cations such as calcium $\left(\mathrm{Ca}^{2+}\right)$ and magnesium $\left(\mathrm{Mg}^{2+}\right)$, major anion like chlorides $\left(\mathrm{Cl}^{-}\right)$of groundwater samples were analyzed by titrimetric methods. Nitrates $\left(\mathrm{NO}_{3}{ }^{-}\right)$ and fluoride $\left(\mathrm{F}^{-}\right)$determination in the groundwater samples were carried out by UV Spectrophotometer.

For heavy metal analysis, all the samples were digested with concentrated nitric acid $\left(\mathrm{HNO}_{3}\right)$ to ensure that samples are free of organic impurities. The digested water samples were analyzed for Iron ( $\mathrm{Fe})$, Manganese $(\mathrm{Mn})$ and Arsenic (As) using iCE 3000 Series Atomic Absorption Spectrometer (Thermo Scientific) with D2 background correction lamp.

The data were statistically analyzed in October, 2016 using Statistical Package for Social Sciences (SPSS v21) software package. Statistical methods like mean, standard deviation and median for all the parameters were categorically analyzed for borewell, tubewell and total underground water samples. Skewness were normalized by logarithmic and square root approach wherever applicable. Pearson correlation analysis at significance level of 0.05 for all 18 water quality parameters was done to evaluate the degree of interrelationship and association between two variables. As null hypothesis it was hypothesized that there were no significant difference between the given parameter of three districts as a whole or in multiple comparisons. One-way ANOVA was performed along with Tukey's HSD among all the three districts for all 18 parameters at significance level of 0.05 . Hierarchical centroid clustering analysis was performed at significance level of 0.05 using agglomeration schedule and squared euclidean distance interval with all parameters as variables and Label Case by District.

\section{Results and discussions}

Results of the physicochemical characteristics for water samples from 135 borewell and 40 tubewell were analyzed and presented below (Tables 1, 2).

\section{Physical characteristics}

Out of 175 groundwater samples, 34 (19.43\%) samples were out of range from 5.0 to 8.59 . $\mathrm{pH}$ is mainly influenced by volume of water and soil type. Acidic $\mathrm{pH}$ of water may be due to the dissolved carbon dioxide and organic acids from decay and subsequent leaching of plant materials [24]. The range of underground water temperature throughout the seasons were from 17.0 to $35.9{ }^{\circ} \mathrm{C}$. As per NDWQS standard, only one sample showed the result above the permissible limit as $1898 \mu \mathrm{S} /$ $\mathrm{cm}$. All the samples were found to be within the WHO and NDWQS guideline value. Turbidity in 78 samples (44.57\%) were above permissible limit. The origin of turbidity may be clay particles, sewage solids, silt and sand washings, organic and biological sludge and some other factors. Turbidity in water may affect its acceptability to consumers [6]. TDS of all the samples were within the permissible limit of WHO and NDWQS (1000 mg/L).

\section{Chemical characteristics}

Though WHO has not recommended any guideline, one sample had hardness above NDWQS guidelines. As per classification of hardness $[7,25,26]$ only $12 \%$ of underground water samples were soft, $9.14 \%$ were moderately hard, $14.86 \%$ were hard and $64 \%$ were very hard. There is no any recommended value for calcium hardness by WHO and NDWQS. Only one sample had alkalinity $512.4 \mathrm{mg} / \mathrm{L}$ above WHO guideline. Alkalinity in itself is not harmful to human being, but in large quantity, alkalinity imparts bitter taste to water and may cause eye irritation [6]. Fluoride ion has both beneficial and harmful impact, if not within range. On the basis of WHO, all samples were well within the recommended limit $(<1.5 \mathrm{mg} / \mathrm{L})$. Chloride $(0.5-161.8 \mathrm{mg} / \mathrm{L})$ and nitrate concentration $(<0.05-3.38 \mathrm{mg} / \mathrm{L})$ of all the samples were below the permissible limit of WHO and NDWQS. The chloride values in the underground water samples may be due to the dissolution of rocks surrounding the aquifer and probably due to the leakage and anthropogenic pollution like agricultural activities [12, 13]. 6 samples $(3.43 \%)$ were above the permissible limit for ammonia concentration. Presence of $\mathrm{NH}_{3}$ in groundwater indicates influence of industrial effluents and organic contaminants [16].

\section{Heavy metals}

Among Fe, Mn, and As analysis; only arsenic was below the permissible limits of WHO and NDWQS. $61.14 \%$ of samples were above the permissible limit for iron concentration. In $50.28 \%$ samples, Mn were found to be above the permissible limit of NDWQS. In the aquifer, groundwater comes in contact with soils, rocks and minerals that naturally contain Fe and $\mathrm{Mn}$ and dissolve them, releasing their constituents, including Fe and $\mathrm{Mn}$, to the water $[27,28]$. In some local areas high iron content indicates industrial effluent, sewage and landfill leachate [29, 30]. Only one sample showed greater value than WHO guidelines. Although there were no significant signs of leaching in all over studied area, contamination was evident in certain industrial surroundings with iron, steel, textile and paints work [31].

\section{Statistical analysis}

Analysis of 175 underground water sample (135 borewell water and 40 tubewell sample) indicated that mean and median of most of the parameters were within WHO and NDWQS guidelines except turbidity (mean \pm standard deviation $12.73 \pm 21.76$; median value 3.29 ), fluoride $(0.235 \pm 0.216 ; 0.16)$, iron $(1.836 \pm 3.642 ; 0.46)$ and 
Table 1 Statistical summary of the physicochemical parameters of borewell water samples collected from the study area

\begin{tabular}{|c|c|c|c|c|c|c|c|c|}
\hline \multirow[t]{2}{*}{ Parameters } & \multirow[t]{2}{*}{ Range } & \multirow[t]{2}{*}{ Mean } & \multirow[t]{2}{*}{ Standard deviation } & \multirow[t]{2}{*}{ Median } & \multirow[t]{2}{*}{ WHO guidelines } & \multirow[t]{2}{*}{$\begin{array}{l}\text { NDWQS } \\
\text { guidelines }\end{array}$} & \multicolumn{2}{|c|}{$\begin{array}{l}\text { Samples } \\
\text { not within limit }\end{array}$} \\
\hline & & & & & & & Number & $\%$ \\
\hline \multicolumn{9}{|l|}{ Borewell $(N=135)$} \\
\hline $\mathrm{pH}$ & $5.00-8.36$ & 6.946 & 0.574 & 7 & $6.5-8.5$ & $6.5-8.5$ & 25 & 18.52 \\
\hline Temp $\left({ }^{\circ} \mathrm{C}\right)$ & $17.8-34.8$ & 28.064 & 4.229 & 28.7 & - & - & - & - \\
\hline $\mathrm{EC}(\mu \mathrm{S} / \mathrm{cm})$ & $14.8-1192.0$ & 433.797 & 233.926 & 433 & - & 1500 & 0 & 0 \\
\hline Turbidity (NTU) & $0.00-93.00$ & 13.508 & 20.929 & 3.44 & 5 & 5 & 63 & 46.67 \\
\hline Color (Hazen) & $0.01-4.10$ & 0.235 & 0.513 & 0.11 & 15 & 5 & 0 & 0 \\
\hline TDS (mg/L) & $7.50-596.00$ & 223.690 & 115.611 & 219.5 & 1000 & 1000 & 0 & 0 \\
\hline $\mathrm{F}^{-}(\mathrm{mg} / \mathrm{L})$ & $0.02-1.04$ & 0.232 & 0.193 & 0.18 & 1.5 & $0.5-1.5$ & $0(119)$ & $0(88.15)$ \\
\hline $\mathrm{NH}_{3}(\mathrm{mg} / \mathrm{L})$ & $0.05-2.53$ & 0.479 & 0.407 & 0.38 & 1.5 & 1.5 & 5 & 3.70 \\
\hline $\mathrm{NO}_{3}^{-}(\mathrm{mg} / \mathrm{L})$ & $0.05-2.83$ & 0.187 & 0.408 & 0.05 & 50 & 50 & 0 & 0 \\
\hline $\mathrm{Cl}^{-}(\mathrm{mg} / \mathrm{L})$ & $0.50-145.45$ & 13.424 & 24.223 & 3 & 250 & 250 & 0 & 0 \\
\hline $\mathrm{TH}(\mathrm{mg} / \mathrm{L})$ & $1.11-510.00$ & 190.875 & 87.955 & 205.35 & - & 500 & 1 & 0.74 \\
\hline $\mathrm{CH}(\mathrm{mg} / \mathrm{L})$ & $1.00-412.62$ & 119.419 & 66.504 & 117.89 & - & - & - & - \\
\hline TA (mg/L) & $2.36-512.40$ & 196.491 & 90.848 & 209.72 & 500 & - & 1 & 0.74 \\
\hline $\mathrm{Fe}(\mathrm{mg} / \mathrm{L})$ & $0.05-23.10$ & 2.030 & 3.945 & 0.59 & 0.3 & 0.3 & 87 & 64.44 \\
\hline $\mathrm{Mn}(\mathrm{mg} / \mathrm{L})$ & $0.05-3.10$ & 0.356 & 0.463 & 0.22 & - & 0.2 & 70 & 51.85 \\
\hline As (mg/L) & $0.005-0.050$ & 0.005 & 0.004 & 0.005 & 0.01 & 0.05 & $1(0)$ & $0.74(0)$ \\
\hline $\mathrm{Ca}^{2+}(\mathrm{mg} / \mathrm{L})$ & $0.00-165.05$ & 45.598 & 26.418 & 42.708 & - & 200 & 0 & 0 \\
\hline $\mathrm{Mg}^{2+}(\mathrm{mg} / \mathrm{L})$ & $0.00-57.07$ & 18.118 & 12.255 & 16.53 & - & - & - & - \\
\hline \multicolumn{9}{|l|}{ Tubewell $(N=40)$} \\
\hline $\mathrm{pH}$ & $5.27-8.59$ & 6.978 & 0.669 & 6.965 & $6.5-8.5$ & $6.5-8.5$ & 9 & 22.5 \\
\hline Temp $\left({ }^{\circ} \mathrm{C}\right)$ & $17.0-35.9$ & 26.563 & 5.603 & 28.5 & - & - & - & - \\
\hline $\mathrm{EC}(\mu \mathrm{S} / \mathrm{cm})$ & $32.2-1898.0$ & 484.998 & 350.855 & 461.5 & - & 1500 & (1) & $(2.5)$ \\
\hline Turbidity (NTU) & $0.00-149.00$ & 10.100 & 24.444 & 1.915 & 5 & 5 & 15 & 37.5 \\
\hline Color (Hazen) & $0.01-1.03$ & 0.164 & 0.202 & 0.125 & 15 & 5 & 0 & 0 \\
\hline TDS (mg/L) & $42.00-949.0$ & 255.820 & 164.383 & 235.0 & 1000 & 1000 & 0 & 0 \\
\hline $\mathrm{F}^{-}(\mathrm{mg} / \mathrm{L})$ & $0.04-1.10$ & 0.245 & 0.283 & 0.14 & 1.5 & $0.5-1.5$ & $0(33)$ & $0(82.5)$ \\
\hline $\mathrm{NH}_{3}(\mathrm{mg} / \mathrm{L})$ & $0.05-3.36$ & 0.472 & 0.545 & 0.38 & 1.5 & 1.5 & 1 & 2.5 \\
\hline $\mathrm{NO}_{3}(\mathrm{mg} / \mathrm{L})$ & $0.05-3.38$ & 0.536 & 0.879 & 0.11 & 50 & 50 & 0 & 0 \\
\hline $\mathrm{Cl}^{-}(\mathrm{mg} / \mathrm{L})$ & $0.50-161.80$ & 29.118 & 40.772 & 8.0 & 250 & 250 & 0 & 0 \\
\hline $\mathrm{TH}(\mathrm{mg} / \mathrm{L})$ & $35.00-349.0$ & 194.241 & 88.628 & 204.5 & - & 500 & 0 & 0 \\
\hline $\mathrm{CH}(\mathrm{mg} / \mathrm{L})$ & $13.35-270.26$ & 116.957 & 65.504 & 107.045 & - & - & - & - \\
\hline TA (mg/L) & $36.4-368.88$ & 201.681 & 87.762 & 215.67 & 500 & - & 0 & 0 \\
\hline $\mathrm{Fe}(\mathrm{mg} / \mathrm{L})$ & $0.05-10.81$ & 1.184 & 2.271 & 0.315 & 0.3 & 0.3 & 20 & 50 \\
\hline $\mathrm{Mn}(\mathrm{mg} / \mathrm{L})$ & $0.05-2.75$ & 0.402 & 0.564 & 0.15 & - & 0.2 & (18) & (45) \\
\hline As (mg/L) & $0.005-0.005$ & 0.005 & 0.000 & 0.005 & 0.01 & 0.05 & 0 & 0 \\
\hline $\mathrm{Ca}^{2+}(\mathrm{mg} / \mathrm{L})$ & $5.34-108.10$ & 43.580 & 25.797 & 40.079 & - & 200 & 0 & 0 \\
\hline $\mathrm{Mg}^{2+}(\mathrm{mg} / \mathrm{L})$ & $1.46-61.49$ & 19.889 & 13.907 & 15.556 & - & - & - & - \\
\hline
\end{tabular}

Numeric values within bracket represent samples number and percentage of samples not within limit as per NDWQS guidelines while those outside are as per WHO guidelines

EC electrical conductivity, TDS total dissolved solutes, TH total hardness, CH calcium hardness, TA total alkalinity, WHO World Health Organization, NDWQS Nepal Drinking Water Quality Standard

manganese $(0.367 \pm 0.486 ; 0.21)$. Fluoride concentration was below the minimum permissible limit of NDWQS, but was within limit of WHO guidelines. The elevated level of iron imparts smell, taste and stain on clothes
[32]. Mean and median of Mn were above the permissible limit. High level of Mn causes water discoloration.

Mean value of tubewell water for total hardness and $\mathrm{Mg}^{2+}$ was greater than borewell water. It indicates that the tubewell water layer has rocks having minerals rich 
Table 2 Statistical summary of the physicochemical parameters of groundwater samples collected from the study area

\begin{tabular}{|c|c|c|c|c|c|c|c|c|}
\hline \multirow[t]{2}{*}{ Parameters } & \multirow[t]{2}{*}{ Range } & \multirow[t]{2}{*}{ Mean } & \multirow[t]{2}{*}{ Standard deviation } & \multirow[t]{2}{*}{ Median } & \multirow[t]{2}{*}{ WHO guidelines } & \multirow[t]{2}{*}{$\begin{array}{l}\text { NDWQS } \\
\text { guidelines }\end{array}$} & \multicolumn{2}{|c|}{$\begin{array}{l}\text { Samples } \\
\text { not within limit }\end{array}$} \\
\hline & & & & & & & Number & $\%$ \\
\hline \multicolumn{9}{|c|}{ Groundwater $(N=175)$} \\
\hline $\mathrm{pH}$ & $5.00-8.59$ & 6.953 & 0.595 & 6.99 & $6.5-8.5$ & $6.5-8.5$ & 34 & 19.43 \\
\hline Temp $\left({ }^{\circ} \mathrm{C}\right)$ & $17.0-35.9$ & 27.721 & 4.606 & 28.5 & - & - & - & - \\
\hline $\mathrm{EC}(\mu \mathrm{S} / \mathrm{cm})$ & $14.8-1898.0$ & 445.500 & 264.949 & 436 & - & 1500 & (1) & $(0.57)$ \\
\hline Turbidity (NTU) & $0.00-149.00$ & 12.729 & 21.756 & 3.29 & 5 & 5 & 78 & 44.57 \\
\hline Color (Hazen) & $0.01-4.10$ & 0.219 & 0.461 & 0.11 & 15 & 5 & 0 & 0 \\
\hline TDS (mg/L) & $7.50-949.00$ & 231.034 & 128.581 & 224 & 1000 & 1000 & 0 & 0 \\
\hline $\mathrm{F}^{-}(\mathrm{mg} / \mathrm{L})$ & $0.02-1.10$ & 0.235 & 0.216 & 0.16 & 1.5 & $0.5-1.5$ & $0(152)$ & $0(86.86)$ \\
\hline $\mathrm{NH}_{3}(\mathrm{mg} / \mathrm{L})$ & $0.05-3.36$ & 0.477 & 0.440 & 0.38 & 1.5 & 1.5 & 6 & 3.43 \\
\hline $\mathrm{NO}_{3}(\mathrm{mg} / \mathrm{L})$ & $0.05-3.38$ & 0.266 & 0.569 & 0.05 & 50 & 50 & 0 & 0 \\
\hline $\mathrm{Cl}^{-}(\mathrm{mg} / \mathrm{L})$ & $0.50-161.8$ & 17.011 & 29.464 & 3.5 & 250 & 250 & 0 & 0 \\
\hline $\mathrm{TH}(\mathrm{mg} / \mathrm{L})$ & $1.11-510.00$ & 191.644 & 87.865 & 205.35 & - & 500 & (1) & $(0.57)$ \\
\hline $\mathrm{CH}(\mathrm{mg} / \mathrm{L})$ & $1.00-412.62$ & 118.856 & 66.097 & 116.23 & - & - & - & - \\
\hline $\mathrm{TA}(\mathrm{mg} / \mathrm{L})$ & $2.36-512.40$ & 197.678 & 89.929 & 213.06 & 500 & - & 1 & 0.57 \\
\hline $\mathrm{Fe}(\mathrm{mg} / \mathrm{L})$ & $0.05-23.10$ & 1.836 & 3.642 & 0.46 & 0.3 & 0.3 & 107 & 61.14 \\
\hline $\mathrm{Mn}(\mathrm{mg} / \mathrm{L})$ & $0.05-3.10$ & 0.367 & 0.486 & 0.21 & - & 0.2 & (88) & $(50.28)$ \\
\hline As (mg/L) & $0.005-.050$ & 0.005 & 0.003 & 0.005 & 0.01 & 0.05 & $1(0)$ & $0.57(0)$ \\
\hline $\mathrm{Ca}^{2+}(\mathrm{mg} / \mathrm{L})$ & $0.00-165.05$ & 45.137 & 26.218 & 41.281 & - & 200 & 0 & 0 \\
\hline $\mathrm{Mg}^{2+}(\mathrm{mg} / \mathrm{L})$ & $0.00-61.49$ & 18.523 & 12.632 & 16.28 & - & - & - & - \\
\hline
\end{tabular}

Numeric values within bracket represent samples number and percentage of samples not within limit as per NDWQS guidelines while those outside are as per WHO EC electrical conductivity, TDS total dissolved solutes, TH total hardness, CH calcium hardness, TA total alkalinity, WHO World Health Organization, NDWQS Nepal Drinking Water Quality Standard

in magnesium comparative to borewell aquifers surroundings. Dolomite is an ore of Mg. Borewell layer may have minerals like calcite or gypsum in excess. Mean and median value of alkalinity were slightly greater in tubewell water than borewell water. With an overall alkalinity mean of $197.678 \pm 89.929$ and median of 213.06 for all groundwater samples, it is clear that the $\mathrm{pH}$ of water is well buffered. Though mean $(0.477 \pm 0.44)$ and median (0.38) value of $\mathrm{NH}_{3}$ for all samples were below the permissible limit, its presence in groundwater is not desirable. Mean and median value of nitrate was below the permissible limit $0.266 \pm 0.569$ and 0.05 .

\section{Correlations}

Electrical conductivity, total dissolved solids, total alkalinity, total hardness, and manganese show good positive correlation with major water quality parameters (Additional file 1: Table S3-S6). Very high correlation between $\mathrm{TA}$ and TH $(r=0.954), \mathrm{CH}$ and $\mathrm{Ca}^{2+}(r=0.922), \mathrm{EC}$ and TDS $(r=0.898)$, and TDS and TH $(r=0.835)$ were seen at $p \leq 0.01$. The moderately significant and positive correlation indicated that the presence of calcium, magnesium, total hardness, calcium hardness and total alkalinity greatly influences TDS, TA and EC.
The correlation value suggested that there was a great dependence of total hardness and alkalinity on calcium hardness, calcium and magnesium. Manganese showed low positive correlation (at $p \leq 0.01$ ) with $\mathrm{TH}$, TA, magnesium, EC, chloride, ammonia, TDS, iron and turbidity. Iron was moderately positive with turbidity and low with ammonia, manganese and color. Though low but positive correlation was shown by ammonia with iron, turbidity, color, manganese, EC, TDS, fluoride and chloride. $\mathrm{NH}_{3}$ presence could alter the color of the water. Low positive correlation of chloride on total hardness, total alkalinity, EC, and magnesium was seen. Fluoride showed a poor but positive correlation (at $p \leq 0.01$ ) with calcium, calcium hardness, color, total alkalinity, EC, ammonia, and TDS. pH was poorly and negatively correlated with turbidity, chloride and iron while low positive correlation was seen with $\mathrm{TH}, \mathrm{CH}, \mathrm{TA}, \mathrm{EC}$, TDS and Ca. Nitrate showed negative and poor correlation with iron and manganese while nitrate was positively correlated with chloride. Temperature, turbidity, fluoride, ammonia and iron were in low positive correlation with color while $\mathrm{TH}$, $\mathrm{CH}, \mathrm{TA}$ and $\mathrm{Mg}$ had poor negative correlation to color.

ANOVA test (Additional file 1: Table S7) showed that $\mathrm{pH}, \mathrm{EC}$, color, TDS, chloride, $\mathrm{TH}, \mathrm{CH}, \mathrm{TA}$, iron, 
manganese, calcium, and magnesium of three districts were highly significant $(d f=2, \alpha=0.05)$. Tukey's HSD analysis (Additional file 1: Table S8) presented a district-wise difference, if exists, in parameters (Detailed interpretation in Additional file 1: Table S8). Profile plot of the marginal means of three districts were plotted (Additional file 1: Fig S2-S19). Dendrogram of several parametric combinations (Additional file 1: Fig S20-S24) were plotted showing Hierarchical Cluster Analysis using agglomeration schedule and centroid clustering.

\section{Conclusion}

Undermining $\mathrm{pH}$, turbidity, ammonia, and iron; groundwater in Eastern Terai Districts can be considered safe for drinking and domestic use with certain measures. Iron concentration is a great concern in all these areas. Additionally, the contamination of groundwater with iron and manganese in industrial corridor is high and must be addressed. There is always a chance of groundwater contamination through chemical wastes in the heavily industrialized area of Morang and Sunsari Industrial corridor. It is, however, recommended that a well-designed groundwater monitoring program be devised to periodically screen hazardous contaminants in water.

\section{Limitations}

Soil analysis for fertilizer, pesticides, other chemicals, and extent of leaching wasn't investigated. Similarly, sewage analysis and analysis of untreated water from industry weren't performed. Other heavy metals except iron, manganese and arsenic were not evaluated in sample.

\section{Additional file}

Additional file 1. Additional Tables and Figures.

\section{Abbreviations}

EC: electrical conductivity; Temp: temperature; Tur: turbidity; TDS: total dissolved solids; $\mathrm{F}^{-}$: fluorides; $\mathrm{NH}_{3}$ : ammonia; $\mathrm{NO}_{3}{ }^{-}$: nitrates; $\mathrm{Cl}^{-}$: chloride; $\mathrm{TH}$ : total hardness; $\mathrm{CH}$ : calcium hardness; Ca: calcium; Mg: magnesium; TA: total alkalinity; Fe: iron; Mn: manganese; As: arsenic; NDWQS: Nepal Drinking Water Quality Standards; WHO: World Health Organization.

\section{Authors' contributions}

SM was involved in planning the research, study design, analysis, and writing the manuscript; SM, PKK and NB was involved in laboratory work and data collection and compiling, SM and AM was involved in preparation of report, statistical analysis, review and editing. All authors read and approved the final manuscript.

\section{Author details \\ ${ }^{1}$ Aasra Research and Education Academy Counsel, Janapriya Tole, Biratna- gar-7, Nepal. ${ }^{2}$ Nepal Batawaraniya Sewa Kendra, Biratnagar-9, Nepal.}

\section{Acknowledgements}

We sincerely appreciate the visionary efforts and inputs of AASRA Research and Education Academy Counsel for making this study possible. We are also thankful to Nepal Batawaraniya Sewa Kendra, Nepal (a NEPLAS accredited lab) and those individuals who made this study possible through their contribution by any means.

\section{Competing interests}

The authors declare that they have no competing interests.

Availability of data and materials

All the required data and material of research is given in the manuscript.

\section{Consent for publication}

Not applicable.

\section{Ethics approval and consent to participate}

Research approval was taken from AASRA Research and Education Academy Counsel, Biratnagar and Nepal Batawaraniya Sewa Kendra, Nepal (a NEPLAS accredited lab). Informed written consent was obtained from all participants.

Funding

No fund/grant was received for the research work.

\section{Publisher's Note}

Springer Nature remains neutral with regard to jurisdictional claims in published maps and institutional affiliations.

Received: 14 February 2018 Accepted: 11 May 2018

Published online: 21 May 2018

\section{References}

1. Sharp KA. Water: structure and properties. Encyclopedia of life sciences. New Jersey: Wiley; 2001

2. Siebert S, Burke J, Faures JM, Frenken K, Hoogeveen J, Doll P, et al. Groundwater use for irrigation-a global inventory. Hydrol Earth Syst Sci. 2010;14:1863-80. https://doi.org/10.5194/hess-14-1863-2010.

3. Harter T. Reference: groundwater quality and groundwater pollution. Oakland: ANR Publication 8084; 2003.

4. Rao NS. Seasonal variation of groundwater quality in a part of Guntur District, Andhra Pradesh, India. Environ Geol. 2006;2006(49):413-29. https //doi.org/10.1007/s00254-005-0089-9.

5. WHO. Total dissolved solids in drinking-water: background document for development of WHO Guidelines for drinking-water quality. Geneva: World Health Organization; 2011.

6. WHO. Guidelines for drinking-water quality. 4th ed. Geneva: World Health Organization; 2011.

7. World Health Organization. Hardness in drinking-water: background document for development of WHO guidelines for drinking-water quality. Geneva: World Health Organization (WHO/HSE/WSH/10.01/10/rev/1); 2011

8. WHO. Calcium and magnesium in drinking-water: public health significance. Geneva: World Health Organization; 2009.

9. WHO. Trace elements in human nutrition: report of a WHO expert committee. World Health Organization (WHO Technical Report Series, No. 532). 1973.

10. Fawell J, Bailey K, Chilton J, Dahi E, Fewtrell L, Magaraet Y. Fluoride in drinking-water. Geneva: World Health Organization, IWA Publishing; 2006.

11. Petersen $P E$, Lennon MA. Effective use of fluorides for the prevention of dental caries in the 21 st century: the WHO approach. Community Dent Oral Epidemiol. 2004;32:319-21.

12. Loizidou M, Kapetanios EG. Effect of leachate from landfills on groundwater quality. Sci Total Environ. 1993;128(1):69-81.

13. McCarthy MF. Should we restrict chloride rather than sodium? Med Hypotheses. 2004;63(1):138-48.

14. WHO. Nitrate and nitrite in drinking-water background document for development of WHO guidelines for drinking-water quality. Geneva: World Health Organization (WHO/SDE/WSH/07.01/16/Rev/1); 2011.

15. Craun GF, Greathouse DG, Gunderson DH. Methaemoglobin levels in young children consuming high nitrate well water in the United States. Int J Epidemiol. 1981;10(4):309-17. 
16. WHO. Ammonia in drinking-water: background document for development of WHO guidelines for drinking-water quality. Geneva: World Health Organization (WHO/SDE/WSH/03.04/01); 2011.

17. ATSDR. Toxicological profile for manganese. Agency for toxic substances and disease registry. Atlanta: ATSDR; 2012.

18. Paßlack N, Mainzer B, Lahrssen-Wiederholt M, et al. Concentrations of strontium, barium, cadmium, copper, zinc, manganese, chromium, antimony, selenium and lead in the equine liver and kidneys. SpringerPlus. 2014:3:343. https://doi.org/10.1186/2193-1801-3-343.

19. Agency for Toxic Substances and Disease Registry (ATSDR). Toxicologica profile for hydraulic fluids. Atlanta: Department of Health and Human Services, Public Health Service; 1997.

20. IARC. Some drinking-water disinfectants and contaminants, including Arsenic. IARC Monogr Eval Carcinog Risks Hum. 2002;84:1-19.

21. Dastgiri S, Mosaferi M, Fizi MAH, Olfati N, Zolali S, Pouladi N, et al. Arsenic exposure, dermatological lesions, hypertension, and chromosomal abnormalities among people in a rural community of Northwest Iran. J Health Popul Nutr. 2010;28(1):14-22.

22. Marahatta S, Dangol BS, Gurung GB. Temporal and spatial variability of climate change over Nepal (1976-2005). Kathmandu: Practical Action Nepal Office; 2009.

23. APHA, AWWA, WEF. Standard methods for examination of water and wastewater. 2nd ed. Washington: American Public Health Association; 2012
24. Langmuir D. Aqueous environmental chemistry. New Jersey: PrenticeHall. Inc.; 1997.

25. Hahn DE. Eutrophication causes consequences and correctives. Washington D.C.: National Academy of Sciences; 1986.

26. McGowan W. Water processing: residential, commercial, light-industrial. 3rd ed. Lisle: Water Quality Association; 2000

27. Hawkes SJ. What is a "Heavy Metal"? J Chem Educ. 1997;74(11):1374. https ://doi.org/10.1021/ed074p1374.

28. Shankar S, Shanker U. Shikha. Arsenic contamination of groundwater: a review of sources, prevalence, health risks, and strategies for mitigation. Sci World J. 2014. https://doi.org/10.1155/2014/304524

29. Berti WR, Jacobs LW. Chemistry and phytotoxicity of soil trace elements from repeated sewage sludge applications. J Environ Qual. 1996. https:// doi.org/10.2134/jeq1996.00472425002500050014x.

30. Abd El-Salam MM, Abu-Zuid Gl. Impact of landfill leachate on the groundwater quality: a case study in Egypt. J Adv Res. 2015;6(4):579-86. https://doi.org/10.1016/j.jare.2014.02.003.

31. WHO. Manganese in drinking-water: background document for development of WHO Guidelines for drinking-water quality. Geneva: World Health Organization (WHO/SDE/WSH/03.04/01); 2011.

32. WHO. Iron in drinking-water: background document for development of WHO guidelines for drinking-water quality. Geneva: World Health Organization (WHO/SDE/WSH/03.04/08); 2011.
Ready to submit your research? Choose BMC and benefit from:

- fast, convenient online submission

- thorough peer review by experienced researchers in your field

- rapid publication on acceptance

- support for research data, including large and complex data types

- gold Open Access which fosters wider collaboration and increased citations

- maximum visibility for your research: over $100 \mathrm{M}$ website views per year

At $\mathrm{BMC}$, research is always in progress.

Learn more biomedcentral.com/submissions 